\title{
DETERMINATION OF FLOW AND VISCOELASTIC PROPERTIES OF THE KYRGYZ ETHNIC FOOD "SÜZMÖ" DEPENDING ON TEMPERATURE AND MOISTURE CONTENT
}

\author{
Janyl ISKAKOVA ${ }^{1 *}$, Jamila SMANALIEVA ${ }^{2}$
}

${ }^{1}$ Environmental Engineering Department, Engineering Faculty, Kyrgyz-Turkish Manas University, pr. Aytmatov 56, 720044, Bishkek, KYRGYZSTAN

${ }^{2}$ Department of Food Production Technology, Technology Faculty, Kyrgyz State Technical University after I. Razzakov, pr. Aytmatov 66, 720044 Bishkek, KYRGYZSTAN

Cite this article as:

Iskakova J., Smanalieva J. 2021. Determination of flow and viscoelastic properties of the Kyrgyz ethnic food "Süzmö" depending on temperature and moisture content. Trakya Univ J Nat Sci, 22(2): 199-205, DOI: 10.23902/trkjnat.925710

Received: 22 April 2021, Accepted: 31 July 2021, Online First: 22 September 2021, Published: 15 October 2021

Edited by:

Ayşe Zeynep Hiçşaşmaz Katnaş

*Corresponding Author:

Jayl Iskakova

janil.iskakova@gmail.com

\section{ORCID iDs of the authors:}

JI. orcid.org/0000-0002-1614-3984

JS. orcid.org/0000-0002-3929-4291

Key words:

Fermented food

Paste

Rheological properties

Viscosity

Flow activation energy

\begin{abstract}
Consumer interest in concentrated protein-rich food is growing. Kyrgyz traditional food Süzmö, which is a highly viscous dairy product that is produced from fermented milk Ayran, needs to be introduced into the dairy industry. In this study, the rheological parameters of this indigenous food product were investigated in steady and dynamic rheological experiments. The flow behaviours of Süzmö were evaluated at six temperatures $(20,30,40$, 50,60 , and $70^{\circ} \mathrm{C}$ ) and suitable rheological models were found. The flow curves of Süzmö at investigated temperatures have the yield stress $\left(\tau_{0}\right)$ values between $32.64 \mathrm{~Pa}$ and $285.87 \mathrm{~Pa}$. The flow properties of Süzmö samples at 20 and $30^{\circ} \mathrm{C}$ correspond to the Bingham model. The Casson model was suitable for describing flow curves at $40,50,60$, and $70^{\circ} \mathrm{C}$ with correlation coefficients $\mathrm{R}=0.9506-0.9973$. The effective viscosity ( $\eta_{\text {eff }}$ ) of Süzmö decreased from 15.88 to $0.26 \mathrm{~Pa} \cdot \mathrm{s}$ with increasing temperature from 20 and $70^{\circ} \mathrm{C}$. The effect of temperature on the viscosity corresponds to the Arrhenius relationship. The calculated activation energy was $61.66 \mathrm{~kJ} /(\mathrm{mol})$. A linear model was defined taking into account the influence of moisture content $(\mathrm{p}>0.05)$ on effective viscosity $\left(\mathrm{\eta}_{\text {eff }}\right)$ and yield stress $\left(\tau_{0}\right)$. A temperature-sweep was performed at 20 to $80^{\circ} \mathrm{C}$ to determine the thermal denaturation of the fermented milk samples. The measured parameters are essential for the industrial production of Süzmö and other concentrated fermented milk products.
\end{abstract}

Özet: Konsantre protein açısından zengin gıdalara tüketici ilgisi artmaktadır. Kırgız geleneksel fermente sütü "Ayran"dan üretilen yüksek viskoziteli bir süt ürünü olan Süzmö, süt endüstrisine kazandırılmalıdır. Bu çalışmada, bu eşsiz gıda ürününün reolojik parametreleri, kararlı ve dinamik reolojik deneylerde araştırılmıştır. Süzmönün akış davranışı altı sıcaklıkta $\left(20,30,40,50,60\right.$ ve $\left.70^{\circ} \mathrm{C}\right)$ değerlendirilmiştir. Akışkan akma gerilimi $\left(\tau_{0}\right)$ 32,64 $\mathrm{Pa}$ ile 285,87 $\mathrm{Pa}$ arasında değişen Newtonian olmayan bir psödoplastik akışkan olarak davranmıştır. 20 ve $30^{\circ} \mathrm{C}^{\prime}$ de Süzmö numunelerinin akış eğrisi için en iyi uyum Bingham modeli uygulanarak bulunmuştur. Casson modeli korelasyon katsayıları $\mathrm{R}=0,9506-0,9973$ ile 40,50, 60 ve $70^{\circ} \mathrm{C}^{\prime}$ deki akış eğrilerine uyan en uygun model olarak bulunmuştur. Sicaklık artışıla birlikte Süzmö'nün efektif viskozitesi $15,88^{\prime}$ den $0,26 \quad \mathrm{~Pa} \cdot \mathrm{s}^{\prime} y e$ düşmüştür. Viskozitenin sıcaklığa bağımlılığı Arrhenius ilişkisine karşılık gelir ve aktivasyon enerjisi $61,66 \mathrm{~kJ} /(\mathrm{mol})$ olarak hesaplanmıştır. Nem içeriğinin $(\mathrm{p}>0.05)$ etkin viskozite ve akma gerilmesi üzerindeki etkisi dikkate alınarak doğrusal bir model tanımlanmıştır. Fermente süt örneklerinin termal denatürasyonunu belirlemek için 20 ila $80^{\circ} \mathrm{C}^{\prime} \mathrm{de}$ bir sıcaklık taraması gerçekleştirilmiştir. Ölçülen parametreler Süzmö'nün endüstriyel üretimi için çok önemlidir.

\section{Introduction}

Dairy products are considered as a main dietary source of minerals like calcium, magnesium, zinc, and Bcomplex vitamins such as B2, B5, B6, and B12 (Huth et al. 2006). Fermentation of food using various starter cultures is one of the oldest and widely used preservation methods (Aryama et al. 2016). In Kyrgyz cuisine, fermented milk Ayran is used in concentrated form. Süzmö is also a concentrated product made from fermented milk (yoghurt) using lactic acid bacteria and removing the whey portion. From the perspective of material science, Süzmö is a highly viscous, semisolid, and protein-rich pasty food. Other concentrated milk 
products, in addition to Süzmö, are known to be consumed in most places of the world. Süzmö is made from cow, sheep, and goat milk and is well known in Turkey as Torba yoghurt, winter yoghurt, Tulum yoghurt, Pesküten, or Süzme (filtered yoghurt) (Güler \& Sanal 2009, Kabak \& Dobson 2011). According to Güler \& Sanal (2009), the nutritional value of Torba yoghurts made using goat and sheep milks was characterized with $25.3-25.4 \%$ total solids, 9.9-10.9\% crude protein, $7.5-9.0 \%$ fat, and $4.3-6.7 \%$ lactose content. The concentration of total solids increases approximately 2.5 times during filtration of yoghurt (Güler \& Sanal 2009). In various countries of the Middle East and the Balkans, concentrated fermented milk is also widely used and called Labneh. Labneh, which has 22-26\% total solids, is very popular in Europe and the USA as Greek yoghurt. Greek yoghurt has a solid content of about 26-33\% (w/w) and contains 10 to $12 \mathrm{~g}$ of protein, whereas an identical serving of traditional yoghurt provides only about 5.2 g (Atamian et al. 2014, Costa et al. 2019). Greek yoghurt contains 5 to $8 \%$ carbohydrates, which is approximately half of the carbohydrates compared to traditional yoghurt (Phadungath 2015). As a healthier alternative, homemakers often used Greek and Greek-style yoghurts to replace cream cheese, sour cream, and mayonnaise. It is also possible to find other concentrated dairy products such as Ymer (Denmark), Skyr (Iceland), Tan or Than (Armenia), Shirkland and Chakka (India), and Leben Zeer (Egypt) (Tamime \& Robinson 2007).

Süzmö is usually produced in very limited amounts at homes in rural areas of Kyrgyzstan. The production method of Süzmö is similar to the production of Turkish Torba yoghurt and consists of the following steps: milking, filtering, heating until $100^{\circ} \mathrm{C}$ and cooling down to $40^{\circ} \mathrm{C} .2 \%$ of previous batches of fermented milk called Ayran is used as a sourdough and fermented for 5-6 $\mathrm{h}$ at $38-37^{\circ} \mathrm{C}$. The obtained fermented milk is ready to consume as fresh Ayran, the rest is transferred to a cloth bag and filtered for several days to remove the whey (Kabak \& Dobson 2011, Kamber 2008). Recently, ultrafiltration, centrifugation, and reverse osmosis methods have been recommended for producing concentrated yoghurt (Ozer 2006, Alirezalu et al. 2019).

In Kyrgyz cuisine, Süzmö is used as an additive to soups, for preparing a drink called Chalap, and mainly for the production of dried food products called Kurut. It is made in the form of balls or cylinders by hand pressing. Kurut is known in many countries under different names, for instance as Akçakatik, Keş, or Pestigen in Turkey (Kabak \& Dobson 2011, Kamber 2008). In Tibet, China, fermented yak milk made by natural fermentation is also known as Kurut (Liu et al. 2011, 2012).

In recent years, Kurut has become popular and considered a snack food among most consumers, even among children. Given the growing consumer demand for Kurut production, it is very important to investigate the technological properties of Süzmö in order to obtain a consumer product with high quality. An important technological parameter of pasty foods is rheological properties as viscosity, flow index and elasticity. Consequently, processing parameters and product quality are mainly dependent on rheological properties (Fischer \& Windhab 2011). There is sufficient data on chemical composition, microbiological and rheological properties, as well as processing parameters of concentrated yoghurt Labneh (Ozer et al. 1998, Abu-Jdayil et al. 2000, AbuJdayil \& Mohameed 2002) and Torba yoghurt, but no information exists about Kyrgyz food Süzmö. Therefore, this research aimed to study the rheological properties of different samples of Süzmö using an absolute rheometer to optimize the domestic technological processes of Kurut.

\section{Materials and Methods}

\section{Materials and sample preparation}

Seven samples of Süzmö freshly produced from skimmed milk (protein content 8-9\%) were purchased from a local market in Bishkek. All samples were kept in plastic bags $(500 \mathrm{~g})$ in a refrigerator at $4-6^{\circ} \mathrm{C}$ until rheological measurements.

\section{Chemical analysis}

Titratable acidity, $\mathrm{pH}$, and moisture content of the samples were investigated according to the methods of AACC International (AACC 2019). For measurement of the $\mathrm{pH}$ values of the samples, a $\mathrm{pH}$ meter SevenCompact S210 (Mettler Toledo, Greifensee, Switzerland) was used. Titratable acidity was measured by potentiometric titration with $\mathrm{NaOH}(0.1 \mathrm{M})$ and calculated as the percentage of lactic acid. Dry matter content was calculated by the difference. The measured physicochemical parameters are given in Table 1.

\section{$\underline{\text { Rheological measurements }}$}

The rheological parameters of Süzmö samples were measured on the rheometer MCR 302 (Anton Paar, Graz, Austria) equipped with a concentric cylinder CC27. All measurements were conducted after equilibration of temperature at $20,30,40,50,60$, and $70^{\circ} \mathrm{C}$. The steady shear viscosity measurements were carried out in up and down regimes: 1) the shear rate gradually increased linearly from 0.1 to $50 \mathrm{~s}^{-1} ; 2$ ) the shear rate was constant at $50 \mathrm{~s}^{-1} ; 3$ ) the shear rate was decreased from 50 to $0.1 \mathrm{~s}$ 1 . The area between up and down curves is calculated as the hysteresis area (in $\mathrm{Pa} / \mathrm{s}$ ).

Table 1. Some physicochemical parameters of Süzmö.

\begin{tabular}{ccccc}
\hline Sample & $\begin{array}{c}\text { Moisture } \\
(\mathbf{\%})\end{array}$ & $\begin{array}{c}\text { Solid } \\
\text { content }(\mathbf{\%})\end{array}$ & $\mathbf{p H}$ & $\begin{array}{c}\text { Titratable } \\
\text { acidity } \\
(\mathbf{g} / \mathbf{1 0 0} \mathbf{g})\end{array}$ \\
\hline \hline $\mathbf{1}$ & 68.18 & 31.82 & 3.27 & 3.48 \\
$\mathbf{2}$ & 78.90 & 21.10 & 3.80 & 5.27 \\
$\mathbf{3}$ & 71.50 & 28.50 & 3.78 & 5.76 \\
$\mathbf{4}$ & 72.00 & 28.00 & 3.76 & 6.57 \\
$\mathbf{5}$ & 69.20 & 30.80 & 3.81 & 3.48 \\
$\mathbf{6}$ & 72.00 & 28.00 & 3.79 & 3.47 \\
$\mathbf{7}$ & 77.50 & 22.50 & 4.80 & 3.72 \\
Average & 72.75 & 27.25 & 3.86 & 4.54 \\
SD & 3.71 & 3.71 & 0.42 & 1.21 \\
\hline \hline
\end{tabular}


The flow curves obtained in the $3^{\text {rd }}$ interval were modelled using classical equations such as Bingham (1) and Casson (2):

$$
\tau=\tau_{0}+\eta_{B p} \cdot \dot{\gamma}
$$

where $\tau_{0}$ is the yield stress, $\dot{\gamma}$ is the shear rate, $\eta_{\mathrm{Bp}}$ Bingham plastic viscosity, $\mathrm{n}$ is the flow behaviour index in the Bingham model.

Casson model:

$$
\tau^{0.5}=\tau_{0}^{0.5}+\eta_{C a} \cdot \dot{\gamma}^{0.5}
$$

where $\eta_{C a}$ is Casson's coefficient of viscosity or is the infinite shear viscosity.

The activation energy $E_{a}(\mathrm{~J} / \mathrm{mol})$ was calculated at maximum shear stress $\left(\dot{\gamma}_{\max }=50 \mathrm{~s}^{-1}\right)$ according to the Arrhenius-type relationship (Eq. 3) at the temperature range $40-70^{\circ} \mathrm{C}$, as described in Iskakova et al. (2019):

$$
\eta=A \exp \left(-\frac{E_{a}}{R T}\right)
$$

where $\mathrm{A}$ is the constant, $\mathrm{R}$ is the ideal gas constant $(8.31 \mathrm{~J} / \mathrm{mol} \cdot \mathrm{K}), \mathrm{T}$ is the absolute temperature $(\mathrm{K})$ (Steffe 1996).

\section{Viscoelastic behaviour}

Curing (denaturation) temperatures of the samples were studied in an oscillatory temperature-sweep experiment in a linear viscoelastic range (LVE) at a strain $\gamma$ of $10^{-3} \%$ and the angular frequency of $1 \mathrm{~Hz}$ as described in Smanalieva \& Senge (2009). The temperature of the samples was increased with a heating rate of $0.5^{\circ} \mathrm{C} / \mathrm{min}$ from 20 to $80^{\circ} \mathrm{C}$. The measured elastic $G^{\prime}$ and loss $G^{\prime \prime}$ moduli provide detailed information on the material elasticity (stored energy in the form of deformation) and viscosity (energy dissipation as heat by internal friction). The curing temperatures according to the oscillatory measurements were determined by the loss factor $\tan \delta$ :

$$
\tan \delta=\mathrm{G}^{\prime \prime} / \mathrm{G}^{\prime}
$$

Thus, the values of $\tan \delta$ above 1 indicate more viscous flow behaviour, while any value below 1 is related to the elastic network response (Steffe et al. 2013).

\section{Statistical analysis}

SPSS software (SPSS Inc., Chicago, IL) was used for regression analysis to model the influence of moisture content on rheological parameters. The RHEOPLUS V 3.61 software (Anton Paar, Ostfildern, Germany) was used for the regression analysis of rheological data to model flow behaviour of Süzmö. All parameters were measured three times.

\section{Results and Discussion}

\section{Effect of shear rate on rheological parameters}

The viscosity of yoghurt depends on both shear and time effects (Benezech \& Maingonnat 1994). The relationship between the dynamic viscosity of Süzmö and the shear rate shows strong shear thinning behaviour (Fig. 1) with high magnitudes of yield stresses $\left(\tau_{0}\right)$ at all investigated temperatures (Fig. 2). The flow properties of Labneh with a total solids content of about $23 \%$ have previously been described as a shear-thinning fluid (AbuJdayil et al. 2000). According to Ozer et al. (1998), shearthinning behaviour occurs due to the progressive destruction of aggregates of casein molecules. The shearthinning flow curves of yoghurt Labneh and other dairy products (e.g., stirred yoghurt and dairy desserts) were described with power-law equation known also as Ostwald - de Waele (Abu-Jdayil et al. 2002, Abu-Jdayil et al. 2000), and the Herschel-Bulkley model (Karlsson et al. 2005). In the current study, the regression analysis of the flow curves for all Süzmö samples was performed according to classical rheological models, such as Herschel-Bulkley, Bingham, and Casson models. The Casson model provided the best fit at $40,50,60$, and $70^{\circ} \mathrm{C}(\mathrm{R}=0.994-0.997)$ and the Bingham model provided the best fit at 20 and $30^{\circ} \mathrm{C}(\mathrm{R}=$ 0.9676-0.9890). Therefore, the structure of Süzmö can be classified as semi-solid (Casson) and similar to a plastic fluid (Bingham). The measured and calculated rheological parameters are given in Table 2.

Table 2. Measured and calculated rheological parameters of Süzmö.

\begin{tabular}{ccccccccc}
\hline \hline $\mathbf{T}\left({ }^{\circ} \mathbf{C}\right)$ & Model & $\boldsymbol{\tau}_{\mathbf{0}}(\mathbf{P a})$ & $\boldsymbol{\eta}_{\mathbf{B p}} \mathbf{\text { or }} \boldsymbol{\eta}_{\mathbf{C a}}(\mathbf{P a} \cdot \mathbf{s})$ & $\mathbf{n}(-)$ & $\mathbf{R}$ & $\mathbf{S D}$ & $\mathbf{A}_{\mathbf{T H}}(\mathbf{P a} / \mathbf{s})$ & $\boldsymbol{\eta}_{\text {eff }}(\mathbf{5 0 / s})(\mathbf{P a} \cdot \mathbf{s})$ \\
\hline \hline $\mathbf{2 0}$ & Bingham & 285.87 & 9.36 & 1.0 & 0.9949 & 6.25 & 32966.37 & 15.08 \\
$\mathbf{3 0}$ & Bingham & 183.75 & 4.58 & 1.0 & 0.9890 & 3.30 & 2655.87 & 8.25 \\
$\mathbf{4 0}$ & Casson & 87.77 & 1.01 & 0.5 & 0.9837 & 2.38 & 2274.50 & 1.90 \\
$\mathbf{5 0}$ & Casson & 73.51 & 0.77 & 0.5 & 0.9967 & 0.76 & 2562.96 & 1.58 \\
$\mathbf{6 0}$ & Casson & 66.78 & 0.47 & 0.5 & 0.9975 & 0.42 & 904.59 & 1.40 \\
$\mathbf{7 0}$ & Casson & 27.51 & 0.74 & 0.5 & 0.9978 & 0.51 & 1090.99 & 0.65 \\
$\mathbf{8 0}$ & Casson & 32.64 & 0.62 & 0.5 & 0.90 & 1.96 & 225.42 & 0.74 \\
\hline \hline
\end{tabular}




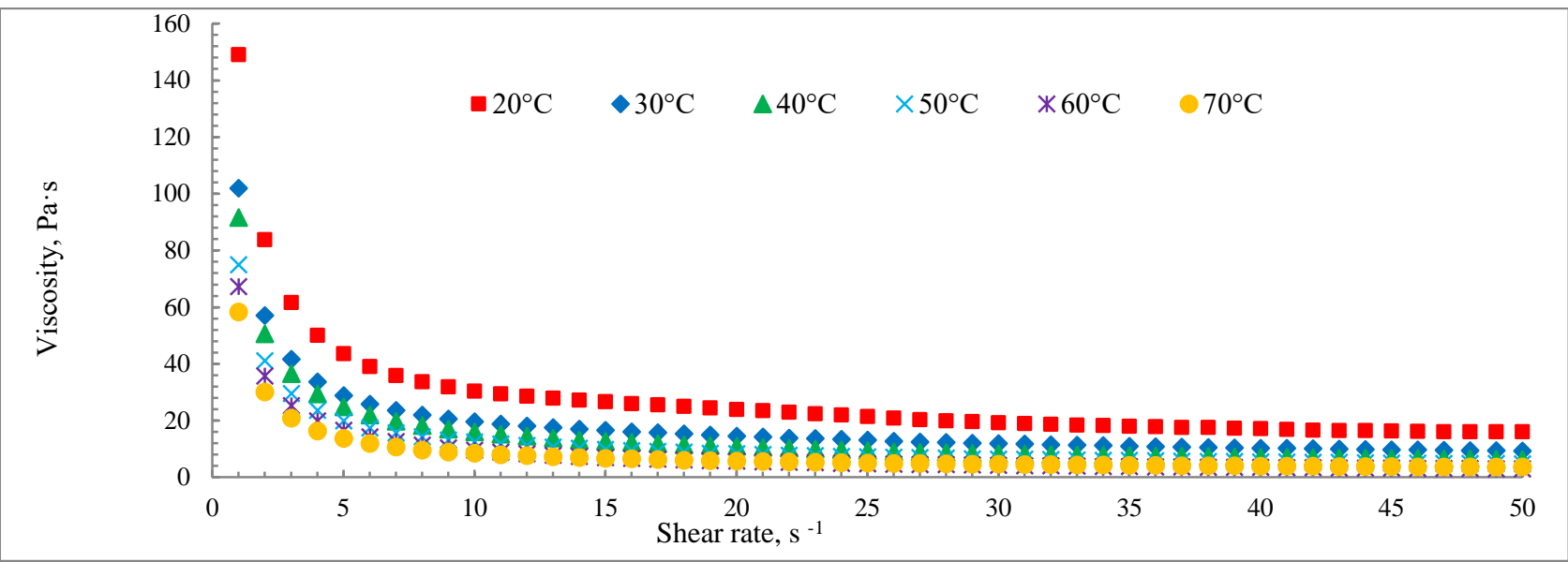

Fig. 1. Dynamic viscosity vs shear rate at $20-70^{\circ} \mathrm{C}$.

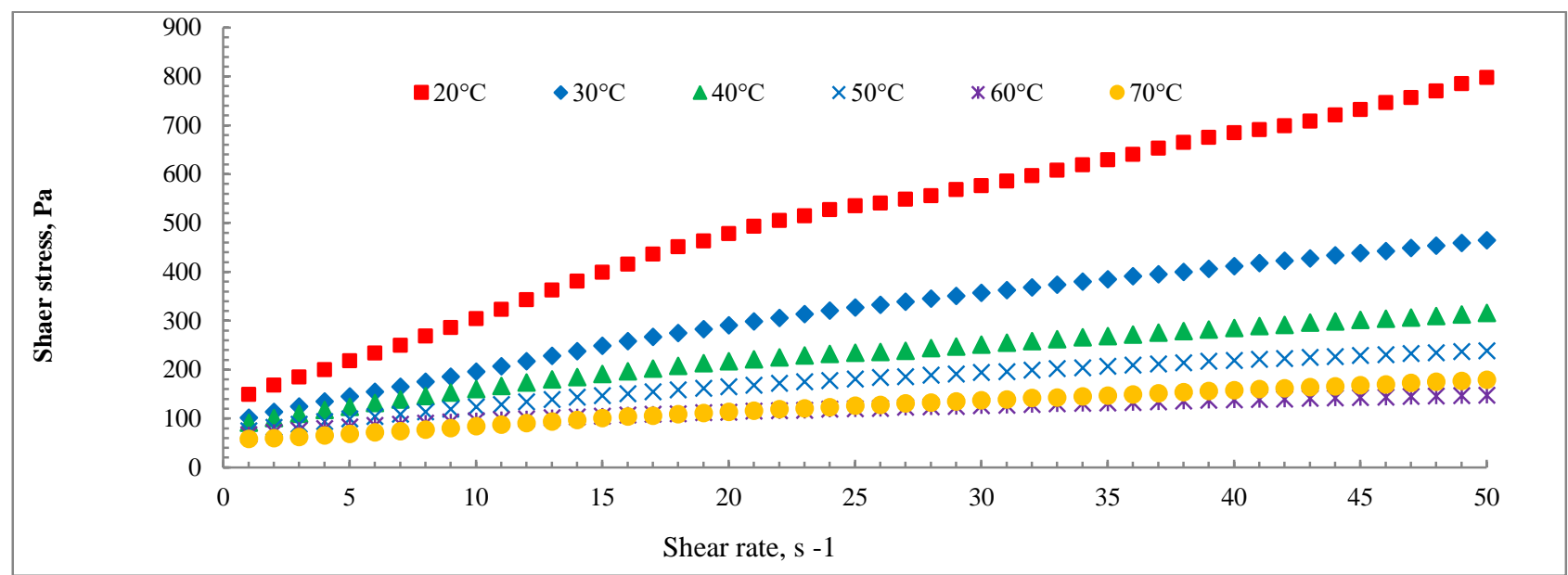

Fig. 2. Shear stress vs shear rate at $20-70^{\circ} \mathrm{C}$.
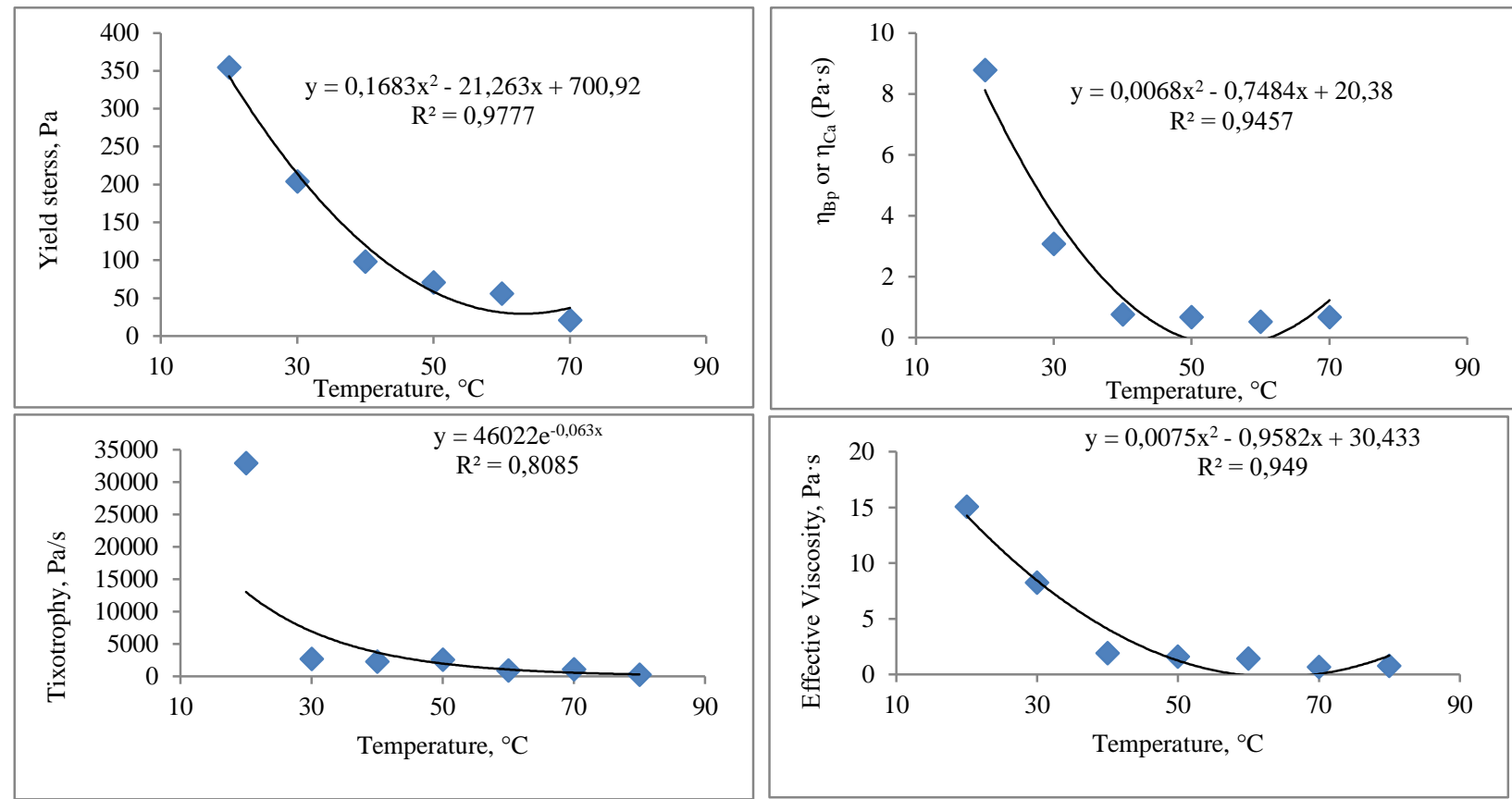

Fig. 3. Temperature effect on yield stress and Bingham $\eta_{\text {Bp }}$ or Casson viscosity $\eta_{C a}$ with rheological parameters. 


\section{Temperature dependence of rheological parameters}

The temperature influence on rheological parameters is shown in Fig. 3. An increase in temperature from 20 to $80^{\circ} \mathrm{C}$ leads to a change in both rheological parameters: the Bingham $\left(\eta_{\mathrm{Bp}}\right)$ or Casson viscosity $\left(\eta_{\mathrm{Ca}}\right)$ drop from 8.78 to $0.67 \mathrm{~Pa} \cdot \mathrm{s}$ and yield stress $\left(\tau_{0}\right)$ - from 285.87 to $32.64 \mathrm{~Pa}$. Accordingly, the effective viscosity, calculated at a shear rate of $50 \mathrm{~s}^{-1}$, decreased from 15.88 to $0.26 \mathrm{~Pa} \cdot \mathrm{s}$. Abu-Jdayil et al. (2002) reported that the viscosity of the Labneh decreases linearly with increasing temperature. Other researchers also reported that the rheological parameters of food materials with the same dry matter content, such as ketchup (Sharoba et al. 2005, Juszczak et al. 2013), milk concentrates (Sauer et al. 2012), or cereal porridges (Iskakova et al. 2017) also depend on temperature.

The influence of temperature on the viscosity of food materials, including concentrated dairy products, is usually described using an Arrhenius-type relationship (Sauer et al. 2012). To obtain the activation energy of Eq. (3), a linear plot of $\ln \left(\eta_{\text {eff }}\right)$ versus $1 / \mathrm{T}$ was plotted (Fig. 4). According to the obtained Eq. from the diagram $\ln \left(\eta_{\text {eff }}\right)=$ $7417.5 \cdot(1 / \mathrm{T})-22.4$, the activation energy was calculated as follows: $E_{a}=61.66 \mathrm{~kJ} /(\mathrm{mol})$. On contrary, $E_{a}$ values for Labneh were lower $21.26 \mathrm{~kJ} / \mathrm{mol}$ (Abu-Jdayil et al. 2000, Abu-Jdayil et al. 2002), for the micellar casein concentrates with reduced 65 and $95 \%$ serum protein were in the ranges of 15.1 to 49.9 and 15.8 to $46.2 \mathrm{~kJ} / \mathrm{mol}$, respectively (Sauer et al. 2012). Krokida et al. (2001) revealed that in foods with Newtonian flow behaviour, the activation energy ranges from $14.4 \mathrm{~kJ} / \mathrm{mol}$ (water) to over $60 \mathrm{~kJ} / \mathrm{mol}$ (concentrated juices and sugar solutions) (Krokida et al. 2001). The value of the pre-exponential parameter A for Süzmö was obtained as 7417.5. This parameter A indicates the internal resistance of the fluid to flow, which is not affected by temperature (Goh 2010). According to Iskakova \& Smanalieva (2020), the activation energy $\left(\mathrm{E}_{\mathrm{a}}\right)$ and coefficient $\mathrm{A}$ for high-fat dairy food Sary mai were 26.3-29.9 KJ/mol and 0.00020.00004 , respectively.

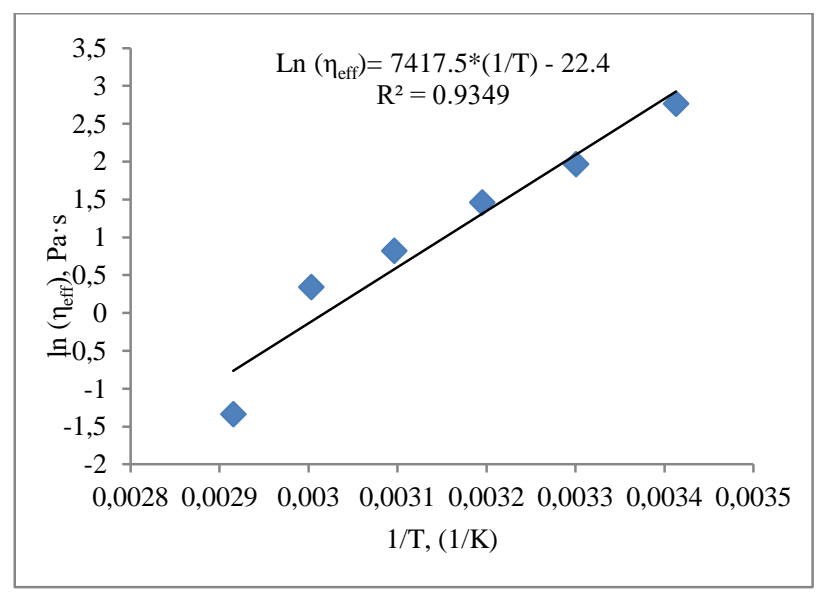

Fig. 4. Arrhenius-type model fit for Süzmö.

Increasing the solids concentration in fermented milk improves the gel formation as a result of the interaction of protein molecules (Mohameed et al. 2004). For mathematical modelling, linear (Eq. 5) and exponential equations (Eq. 6-7) were proposed for the dependence of rheological properties of concentrated milk on the solids content (Reddy \& Datta 1994, Vélez-Ruiz \& BarbosaCánovas 2000):

$$
\begin{aligned}
& n=A X+b \\
& n=A_{n} \exp ^{b n X} \\
& K=A_{k} \exp ^{b k X}
\end{aligned}
$$

where $\mathrm{n}$ is the flow behaviour index, $\mathrm{X}$ is the solid concentration $(\mathrm{X} \mathrm{w} / \mathrm{w}), \mathrm{K}$ is the consistency coefficient $\left(\mathrm{Pa} \cdot \mathrm{s}^{\mathrm{n}}\right.$ ), and $\mathrm{A}, \mathrm{b}$ are constants (Vélez-Ruiz \& BarbosaCánovas 2000).

The moisture contents of the investigated Süzmö samples ranged from 68.18 to $77.55 \%$, thus the average moisture content (W) was $73.28 \%$ w/w. For mathematical modelling of the dependence of rheological parameters on temperature and moisture content, the linear regression analysis was carried out using the SPSS software. The relationship between moisture content, yield stress, and effective viscosity for all tested Süzmö samples can be expressed by Eq. 8:

$$
\mathrm{W}=70.28+0.56 \tau_{0}-0.79 \eta_{\mathrm{eff}}
$$

where $\mathrm{W}$ is the moisture content $(\% \mathrm{w} / \mathrm{w}), \tau_{0}$ is the yield stress $(\mathrm{Pa})$, and $\eta_{\text {eff }}$ is the effective viscosity $(\mathrm{Pa} \cdot \mathrm{s})$ calculated at a shear rate of $50 \mathrm{~s}^{-1}$. Thus, it can be stated that the rheological parameters of concentrated fermented milk Süzmö also depend on the moisture content.

Determination of curdling/denaturation temperature of Süzmö (Temperature-Sweep)

Fig. 5 shows changes in elastic $\left(\mathrm{G}^{\prime}\right)$ and loss $\left(\mathrm{G}^{\prime \prime}\right)$ moduli depending on temperature. The $\mathrm{G}^{\prime}$ is greater than the $\mathrm{G}^{\prime \prime}$, consequently, $\tan \delta$ is below 1 , Süzmö can be classified as a viscoelastic gel system. The $G^{\prime}$ and $G^{\prime \prime}$ values increase with decreasing temperature to $60^{\circ} \mathrm{C}$. Above $60^{\circ} \mathrm{C}$, structural compaction or hardening of the gel occurs, with the $\mathrm{G}^{\prime}$ modulus remaining stable and $\mathrm{G}^{\prime \prime}$ further decreasing, indicating that Süzmö in the temperature scale becomes stronger and the number of individual protein-protein interactions increase due to heating. Ozer et al. (1999) stated that the gel strength of Labneh measured using amplitude- and frequency-sweep modes is mainly dependent on protein content (Ozer et al. 1999, Nsabimana et al. 2005). According to Lee \& Lucey (2004), heating provides energy to increase the entropy of the system, allowing proteins to accept intermediate structures that are important for protein-protein interactions (Lee \& Lucey 2004). Thus, the result of the temperature sweep showed that the temperature of Süzmö should be below $60^{\circ} \mathrm{C}$ to avoid a hard consistency of the final product Kurut. 


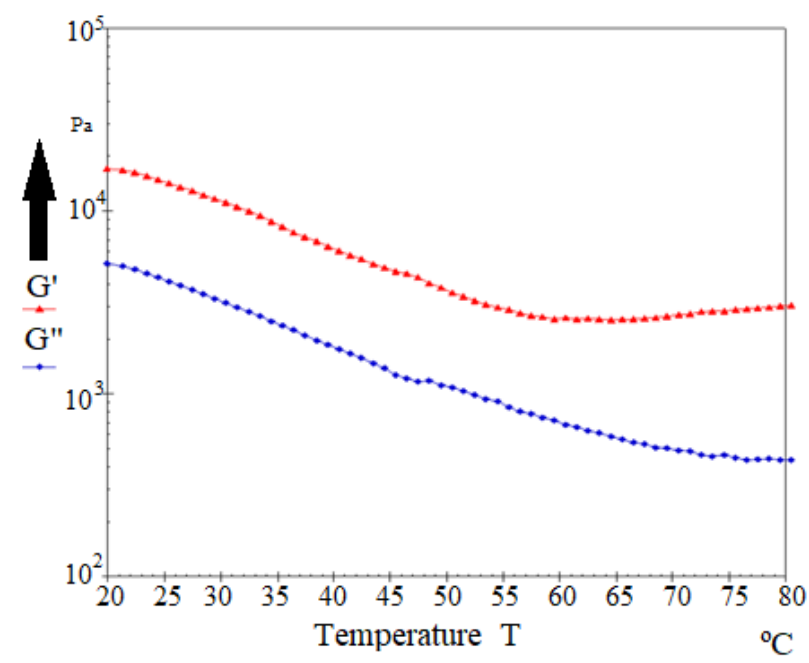

Fig. 5. Temperature-sweeps of Süzmö (heating from 20 to $80^{\circ} \mathrm{C}$ ).

\section{Conclusion}

Seven batches of protein-rich food product Süzmö were tested to understand the dependence of rheological parameters on temperature and moisture content. The values of the rheological parameters such as consistency coefficient, yield stress, and apparent viscosity of the tested samples decreased with increasing temperature.

\section{References}

1. AACC. 2019. Official Methods of Analysis, $21^{\text {st }}$ Edition AOAC International.

2. Abu-Jdayil, B., Jumah, R. \& Shaker, R. 2002. Rheological properties of a concentrated fermented product, labneh, produced from bovine milk: Effect of production method. International Journal of Food Properties, 5(3): 667-679.

3. Abu-Jdayil, B., Shaker, R. \& Jumah, R.2000. Rheological behavior of concentrated yogurt (Labneh). International Journal of Food Properties, 3(2): 207-216.

4. Abu-Jdayil, B. \& Mohameed, H. 2002. Experimental and modelling studies of the flow properties of concentrated yogurt as affected by the storage time. Journal of Food Engineering, 52(4): 359-365.

5. Alirezalu, K., Inácio, R. S., Hesari, J., Remize F., Nematia, Z., Saraiva, J. A., Barba, F.J, Sant'Ana, A. S. \& Lorenzo, J.M. 2019. Nutritional, chemical, syneresis, sensory properties and shelf life of Iranian traditional yoghurts during storage. LWT - Food Science and Technology, 114: 108417 .

6. Aryama, M, Nöbel, S. \& Hinrichs, J. 2016. Post-processing of fermented milk to stirred products: Reviewing the effects on gel structure. Trends in Food Science and Technology, 54: $26-36$.

7. Atamian, S., Olabi, A., Kebbe Baghdadi, O. \& Toufeili, I. 2014. The characterization of the physicochemical and sensory properties of full-fat, reduced-fat and low-fat bovine, caprine, and ovine Greek yogurt (Labneh). Food Science and Nutrition, 2(2): 164-173.

8. Benezech, T. \& Maingonnat, J.F. 1994. Characterization of the rheological properties of yoghurt-A review. Journal of Food Engineering, 21(4): 447-472.
Temperature dependence of effective viscosity was calculated using an Arrhenius-type equation. The linear regression analysis was carried for modelling the effect of moisture content $(\mathrm{p}>0.05)$ on rheological parameters such as effective viscosity and yield stress. The temperature sweep revealed that Süzmö can be classified as a typical viscoelastic gel system. When heated above $60^{\circ} \mathrm{C}$, the gel hardens, so the recommended drying temperature should be below $60^{\circ} \mathrm{C}$, to avoid a hard consistency of Kurut. The parameters obtained can be used by food manufacturers to control the quality of Süzmö and Kurut.

Ethics Committee Approval: Since the article does not contain any studies with human or animal subject, its approval to the ethics committee was not required.

Author Contributions: Concept: J.I., J.S., Desing: J.I., J.S., Execution: J.I., J.S., Material supplying: J.I., J.S., Data acquisition: J.I., J.S., Data analysis/interpretation: J.I., J.S., Writing: J.I., J.S., Critical review: J.I., J.S.

Conflict of Interest: The authors have no conflicts of interest to declare.

Funding: The authors declared that this study has received no financial support.

9. Costa, M.F., Pimentel, T.C., Guimaraes, J.T., Balthazar, C.F., Rocha, R.S., Cavalcanti, R.N., Esmerino, E.A., Freitas, M.Q., Raices, R.S.L., Silva, M.C. \& Cruz, A.G. 2019. Impact of prebiotics on the rheological characteristics and volatile compounds of Greek yogurt. LWT - Food Science and Technology, 105: 371-376.

10. Fischer, P. \& Windhab, E.J. 2011. Rheology of food materials. Current Opinion in Colloid \& Interface Science, 16(1): 36-40.

11. Goh, E.G. 2010. The hidden property of Arrhenius-type relationship: viscosity as a function of temperature. Journal of Physical Science, 21(1): 29-39.

12. Güler, Z. \& Şanal, H. 2009. The essential mineral concentration of Torba yoghurts and their wheys compared with yoghurt made with cows', ewes' and goats' milks. International Journal of Food Sciences and Nutrition, 60(2): 153-164.

13. Huth, P.J., DiRienzo, D.B. \& Miller, G.D. 2006. Major Scientific Advances with Dairy Foods in Nutrition and Health, Journal of Dairy Science, 89(4): 1207-1221.

14. Iskakova, J., Smanalieva, J., Kulmyrzaev, A., Fischer, P. \& Methner, F.-J. 2017. Comparison of rheological and colorimetric measurements to determine $\alpha$-amylase activity for malt used for the beverage Bozo. International Journal of Food Properties, 20(9): 2060-2070.

15. Iskakova, J., Smanalieva, J. \& Methner, F.-J. 2019. Investigation of changes in rheological properties during processing of fermented cereal beverages. Journal of Food Science and Technology, 56(9): 3980-3987. 
16. Iskakova, J. \& Smanalieva, J. 2020. Investigation of rheological behavior of Kyrgyz traditional food Sary mai. Manas Journal of Engineering, 8(2): 84-89.

17. Juszczak, L., Oczadły, Z. \& Gałkowska, D. 2013. Effect of modified starches on rheological properties of ketchup. Food and Bioprocess Technology, 6(5): 1251-1260.

18. Kabak, B. \& Dobson, A.D.W. 2011. An introduction to the traditional fermented foods and beverages of Turkey. Critical Reviews in Food Science and Nutrition, 51(3): 248260.

19. Kamber, U. 2008. The manufacture and some quality characteristics of kurut, a dried dairy product. International Journal of Dairy Technology, 61(2): 146-150.

20. Karlsson, A.O., Ipsen, R., Schrader, K. \& Ardo, Y. 2005. Relationship between physical properties of casein micelles and rheology of skim milk concentrate. Journal of Dairy Science, 88: 3784-3797.

21. Krokida, M. K., Maroulis, Z.B. \& Saravacos, G.D. 2001. Rheological properties of fluid fruit and vegetable puree products: compilation of literature data, International Journal of Food Properties, 4(2): 179-200.

22. Ozer, B. 2006 Production of concentrated products. Pp. 128-155. In: Tamime (ed): Fermented milks. Blackwell Publishing Ltd Oxford, United Kingdom, 250 pp.

23. Lee, W.J. \& Lucey, J.A. 2004. Structure and physical properties of yogurt gels: effect of inoculation rate and incubation temperature. Journal of Dairy Science, 87(10): 3153-3164.

24. Liu, S., Han, Y. \& Zhou, Z. 2011. Lactic acid bacteria in traditional fermented Chinese foods. Food Research International, 44(3): 643-651.

25. Liu, W.J., Sun, Z.H., Zhang, Y.B., Zhang, C.L., Menghebilige, Yang, M., Sun, T.S., Bao, Q.H., Chen, W. \& Zhang, H.P. 2012. A survey of the bacterial composition of kurut from Tibet using a culture-independent approach. Journal of Dairy Science, 95(3): 1064-1072.

26. Mohameed, H.A., Abu-Jdayil, B. \& Al-Shawabkeh, A. 2004. Effect of solids concentration on the rheology of labneh (concentrated yogurt) produced from sheep milk. Journal of Food Engineering, 61(3): 347-352.

27. Nsabimana, C., Jiang, B. \& Kossah, R. 2005. Manufacturing, properties and shelf life of labneh: a review, International Journal of Dairy Technology, 8: 129137.

28. Ozer, B.H., Bell, A.E., Grandison, A.S. \& Robinson, R.K. 1998. Rheological properties of concentrated yoghurt (Labneh). Journal of Texture Studies, 29(1): 67-79.

29. Ozer, B. 2006. Production of concentrated products. Pp. 128-155. In: Tamime (ed): Fermented milks. Blackwell Publishing Ltd Oxford, United Kingdom, 250 pp.

30. Ozer, B.H., Stenning, R.A., Grandison, A.S. \& Robinson, R.K. 1999. Rheology and microstructure of Labneh (Concentrated Yogurt). Journal of Dairy Science, 82(4): 682-689.

31. Phadungath, C. 2015. Greek-style yogurt and its application in cheesecake. International Journal of Food Engineering, 1: 13-17.

32. Reddy, C.S. \& Datta, A.K. 1994. Thermophysical properties of concentrated reconstituted milk during processing. Journal of Food Engineering, 21(1): 31-40.

33. Sauer, A., Doehner, I. \& Moraru, C.I. 2012. Steady shear rheological properties of micellar casein concentrates obtained by membrane filtration as a function of shear rate, concentration, and temperature. Journal of Dairy Science, 95(10): 5569-5579.

34. Sharoba, A.M., Senge, B., El-Mansy, H.A., Bahlol, H.E. \& Blochwitz, R. 2005. Chemical, sensory and rheological properties of some commercial German and Egyptian tomato ketchups. European Food Research and Technology, 220(2): 142-151.

35. Smanalieva, J. \& Senge, B. 2009. Analytical and rheological investigations into selected unifloral German honey. European Food Research and Technology, 229(1): 107-113.

36. Steffe, J.F. 1996. Rheological methods in food process engineering. Second Edition. Freeman Press, East Lansing, $428 \mathrm{pp}$.

37. Tamime, A.Y. \& Robinson, R.K. 2007. Historical background. Pp.1-12. In: Tamime, A.Y. \& Robinson, R.K. (eds). Tamime and Robinson's Yoghurt: Science and Technology. Woodhead Publishing Limited, Boca Raton, $791 \mathrm{pp}$.

38. Vélez-Ruiz, J.F. \& Barbosa-Cánovas, G.V. 2000. Flow and structural characteristics of concentrated milk. Journal of Texture Studies, 31(3): 315-333. 